Article

\title{
Synthesis and Conformational Characteristics of Thermosensitive Star-Shaped Six-Arm Polypeptoids
}

\author{
Tatyana Kirila*(D), Anna Smirnova, Alla Razina, Andrey Tenkovtsev and Alexander Filippov \\ Institute of Macromolecular Compounds of the Russian Academy of Sciences, Bolshoy pr., 31, 199004 Saint \\ Petersburg, Russia; av.smirnova536@gmail.com (A.S.); allarazina@yahoo.com (A.R.); avt@hq.macro.ru (A.T.); \\ afil@imc.macro.ru (A.F.) \\ * Correspondence: tatyana_pyx@mail.ru; Tel.: +7-812-328-4102
}

Received: 3 March 2020; Accepted: 28 March 2020; Published: 3 April 2020

\begin{abstract}
Star-shaped six-arm poly-2-alkyl-2-oxazine and poly-2-alkyl-2-oxazoline with hexaaza [26] orthoparacyclophane derivative core were synthesized successfully using cationic ring-opening polymerization. Conformational behavior of prepared polymer stars were investigated by the methods of molecular hydrodynamics and optics in molecular dispersed solutions. It was shown that conformation characteristics of star-shaped polypeptoids depends on arm length, while the chemical structure weakly affects the behavior of the studied polymers in solutions. This behavior is caused by the close equilibrium rigidity of arms. The star-shaped polypeptoids have relatively high intramolecular density. All synthesized stars exhibit LCST behavior. Phase separation temperature depends on arm structure. It is lower for poly-2-alkyl-2-oxazines, monomer units of which contains one methylene group more than monomers of poly-2-alkyl-2-oxazoline.
\end{abstract}

Keywords: star-shaped polypeptoids; poly-2-alkyl-2-oxazines and poly-2-alkyl-2-oxazolines; synthesize; molecular hydrodynamics and optics; conformational and hydrodynamic characteristics; thermosensitivity

\section{Introduction}

At present star-shaped polymers of amphiphilic nature are the subject of intensive research, since such systems are considered as promising structures for drug delivery systems and other biomedical applications [1,2]. It was shown that transition from linear to star-shaped macromolecules significantly increases the polymer's ability of molecular recognition [3,4]. Special attention is paid to the derivatives of polyethylene oxide and polyalkyloxazolines, which is resulting from their biocompatibility and the ability to show low critical solution temperature (LCST) behavior, which allows controlling the processes of complexation of low-molecular compounds [5-8]. It should be pointed out that incorporation into the polymer of such moieties as macrocycles, for example calixarenes, cyclodextrins, etc., leads to a significant increase of the affinity of these macromolecules to low-molecular compounds and metal ions.

Star-shaped polymers with an azacyclophane core have not been described so far due to the low synthetic availability of parent macrocycles. On the other hand, hexaaza[2 6 ]orthoparacyclophanes can be obtained through preparative yields by reduction of the corresponding macrocyclic Schiff bases, which can be easily prepared by cyclocondensation of aromatic dialdehydes with diamines $[9,10]$. It was found [11-14] that these compounds and their hydrogenated derivatives (macrocyclic polyamines) form stable complexes of a certain stoichiometry with various aromatic compounds and metal ions. These complexes exhibit higher stability in comparison with the similar ones based on calixarene type macrocycles [11]. Functionalization of macrocycle amino groups by methods developed by the authors during the elaboration the synthetic approaches to star-shaped polymers based on calix[8]arene [15], makes it possible to obtain polyfunctional initiators suitable for producing 
star-shaped poly-2-alkyl-2-oxazines (PAlOz) and poly-2-alkyl-2-oxazolines (PAlOx)-the new classes of water-soluble polymers with high affinity to aromatic compounds of various natures and complexes based on them.

To date, a large number of PAlOx have been obtained, including statistical, block and gradient copolymers, grafted and star-shaped polymers [16-20]. The polymerization processes are studied in detail, in particular, the kinetics of oxazolines polymerization that have been initiated by alkyl halides, tosylates, nosylates and triflates [21,22]. For PAlOx, the relations between their chemical structure and the behavior in aqueous solutions were established and features distinguishing them from other thermosensitive polymers were revealed [23-26]. It is shown that the insertion into the polymer of special moieties that are capable of effective binding with inorganic ions and organic compounds is a promising strategy for the construction of supramolecular colloidal structures, which allow simulating the processes occurring in nature [27]. For star-shaped PAlOx, the influence of the length and number of arms on the processes of self-organization and aggregation was established [28-30].

Homologues of PAlOx, namely, poly-2-alkyl-2-oxazines have not been studied, although it is well known that they can be obtained by cationic ring-opening polymerization [31]. However, the process is characterized by low polymerization rate constants and high rate of chain transfer, which makes it difficult to obtain high-molar-mass samples [32-34]. This is one of the reasons for the small number of papers devoted to the study of this promising class of thermosensitive polymers. Poly-2-ethyl-2-oxazine (PEtOz) and poly-2-isopropyl-2-oxazine ( $\mathrm{PiPrOz})$ have been shown to be water-soluble thermosensitive polymers [35,36]. As for PAlOx, hydration of $\mathrm{PAlOz}$ determines the structure of the lateral moieties [37,38]. In particular, by changing the substitute structure in the 2-oxazine monomer, it is possible to obtain a hydrophilic or lipophilic polymer or a combination of two types of monomers-amphiphilic block copolymers [39]. The additional methylene group in the main chain makes PAlOz more hydrophobic in comparison with PAlOx having the same lateral alkyl radical, which leads to the decrease in turbidity temperatures of their aqueous solutions [33]. The most significant is the fact that $\mathrm{PAlOz}$ have much higher binding ability to incorporate water-insoluble drugs in comparison with PAlOx [38]. This indicates a very good prospects for using PAlOz in medicine, but, unfortunately, studies of this class of polymers are just at the initial stage. In the literature, data on the synthesis of PAlOz of complex architecture are few [40].

In this study, new six-arm polymer stars with PAlOx and $\mathrm{PAlOz}$ arms were prepared by cationic ring-opening polymerization (CROP). The derivative of hexaaza[2 $\left.{ }_{6}\right]$ orthoparacyclophane (CPh6) was a multicenter initiator. Accordingly, we examined the star-shaped poly-2-ethyl-2-oxazine (CPh6-PEtOz), poly-2-isopropyl-2-oxazine (CPh6-PiPrOz), poly-2-ethyl-2-oxazolines (CPh6-PEtOx), and poly-2-isopropyl-2-oxazolines (CPh6-PiPrOx). For molar mass characterization and conformational studies, we employed static and dynamic light scattering in combination with viscometry in molecularly dispersed solutions. The LCST behavior was tested by light scattering and turbidimetry.

\section{Materials and Methods}

\subsection{Polymer Star Synthesis}

The solvents and reagents (all Sigma-Aldrich, St. Louis, MO, USA) were purified and dried according to the standard techniques. Trianglamine (1) [11] as well as 2-alkyl-2-oxazolines and 2-alkyl-2-oxazines [41] were synthesizes by the generally applied methods.

\subsubsection{Preparing of Hexa-N-(11-bromoundecanoyl) Trianglamine (2)}

A flask equipped with a stirrer and a gas-supplying tube was charged with $1\left(0.13 \mathrm{~g}, 2 \times 10^{-4} \mathrm{~mol}\right)$, $\mathrm{Cs}_{2} \mathrm{CO}_{3}\left(0.5 \mathrm{~g}, 2.4 \times 10^{-3} \mathrm{~mol}\right)$, and acetonitrile $(8 \mathrm{~mL})$. The mixture was cooled up to $0{ }^{\circ} \mathrm{C}$, and the solution of 11-bromoalkanoic acid chloride $\left(0.69 \mathrm{~g}, 2.4 \times 10^{-3} \mathrm{~mol}\right)$ in acetonitrile $(3 \mathrm{~mL})$ was added under intense stirring. The mixture was allowed to stay at room temperature for two days diluted with water $(20 \mathrm{~mL})$, extracted by methylene chloride and dried over magnesium sulfate. The product 
was purified by flash chromatography silica 100/160 mesh, ethyl acetate/hexane 1:10). Yield 0.45 $\mathrm{g}$ (56\%). ${ }^{1} \mathrm{H} \mathrm{NMR}\left(\mathrm{CDCl}_{3}\right): 7.10(\mathrm{~s}), 5.05$ - $4.9(\mathrm{~m}), 4.07(\mathrm{t}), 3.43(\mathrm{t}), 2.47(\mathrm{t}), 2.34(\mathrm{~m}), 1.87$ (quint), 1.67 (m), $1.31-1.27(\mathrm{~m})$.

NMR spectrum of the initial macrocycle is given in Supplementary Materials (Figure S1).

\subsubsection{Polymerization of Oxazolines(Oxazines) Using 2 As Initiator. Typical Procedure}

An ampoule containing the desired amount of initiator (of about $200 \mathrm{mg}$ ), the appropriate amount of 2-alkyl-2-oxazine or 2-alkyl-2-oxazoline (initiator: monomer $=1: 30$ in terms of functional groups), and $3 \mathrm{~mL}$ of sulfolane was frozen to $-196{ }^{\circ} \mathrm{C}$, air was removed under vacuum $(0.1 \mathrm{~mm} \mathrm{Hg})$, and the mixture was thawed in argon atmosphere. The cycle was repeated three times, then the ampoule was sealed and heated at $100{ }^{\circ} \mathrm{C}$ for $72 \mathrm{~h}$. Further $50 \%$ aqueous ethanol $(1 \mathrm{~mL})$ was added, and the resulting mixture was allowed to stay at room temperature for $24 \mathrm{~h}$. The reaction mixture was dialyzed against water for $24 \mathrm{~h}$, and lyophilized.

Star-shaped poly-2-isopropyl-2-oxazoline: ${ }^{1} \mathrm{H} \mathrm{NMR}\left(\mathrm{CDCl}_{3}\right)$ : $\delta \mathrm{ppm} .4 .16(\mathrm{~m}, \mathrm{core}) 3.88$ (m, core), 3.37 (m, core), 3.47 (br.s $\mathrm{CH}_{2} \mathrm{CH}_{2} \mathrm{~N}$ ), 2.92, 2.68 (br. s $\mathrm{CH}\left(\mathrm{CH}_{3}\right)_{2}$, rotamers), 1.61 (m, core), 1.29 (m, $\mathrm{CH}_{3}+$ core).

Star-shaped poly-2-isopropyl-2-oxazine: ${ }^{1} \mathrm{H} \mathrm{NMR}\left(\mathrm{CDCl}_{3}\right): \delta \mathrm{ppm} .4 .20(\mathrm{~m}, \mathrm{core}) 3.88$ (m, core), $3.33\left(\mathrm{~m} \mathrm{CH}_{2} \mathrm{CH}_{2} \mathrm{CH}_{2} \mathrm{~N}\right), 2.72$ (br. s CH$\left(\mathrm{CH}_{3}\right)_{2}, 1.80\left(\mathrm{~m} \mathrm{CH}_{2} \mathrm{CH}_{2} \mathrm{CH}_{2} \mathrm{~N}\right) 1.85$ (m, core), 1.52 (m, core) $1.29\left(\mathrm{~m}, \mathrm{CH}_{3}+\right.$ core $)$.

Star-shaped poly-2-ethyl-2-oxazoline: ${ }^{1} \mathrm{H} \mathrm{NMR}\left(\mathrm{CDCl}_{3}\right): \delta \mathrm{ppm} .4 .56(\mathrm{~m}, \mathrm{core}) 3.96(\mathrm{~m}, \mathrm{core})$, 3.73 ((m, core), 3.45 (br.s $\left.\mathrm{CH}_{2} \underline{\mathrm{CH}_{2}} \mathrm{~N}\right), 2.42,2.32$ (br. s $\underline{\mathrm{CH}}\left(\mathrm{CH}_{3}\right)_{2}$, rotamers), 1.61 (m, core), 1.29 (m, $\mathrm{CH}\left(\mathrm{CH}_{3}\right)_{2}+$ core $)$.

Star-shaped poly-2-isopropyl-2-oxazine: ${ }^{1} \mathrm{H}$ NMR $\left(\mathrm{CDCl}_{3}\right): \delta \mathrm{ppm} .4 .11(\mathrm{~m}$, core) $3.31(\mathrm{~m}$ $\mathrm{CH}_{2} \mathrm{CH}_{2} \underline{\mathrm{CH}_{2}} \mathrm{~N}+$ core), 2.31 (br. s $\underline{\mathrm{CH}}\left(\mathrm{CH}_{3}\right)_{2}, 2.07$ (m, core), $1.80\left(\mathrm{~m} \mathrm{CH}_{2} \underline{\mathrm{CH}_{2}} \mathrm{CH}_{2} \mathrm{~N}\right) 1.52$ (m, core) 1.29 (m, $\mathrm{CH}_{3}+$ core).

NMR spectra of the prepared polymer stars are given in Figure S2.

\subsection{Solution Investigation}

The molar masses (MM) of the synthesized stars were obtained by sedimentation-diffusion analysis in dilute solutions in chloroform (density $\rho=1.486 \mathrm{~g} \cdot \mathrm{cm}^{-3}$, dynamic viscosity $\eta_{0}=0.57 \mathrm{cP}$, and refractive index $\mathrm{n}_{0}=1.446$ ). The velocity sedimentation experiments were performed on the MOM-3180 analytical ultracentrifuge (Budapest, Hungary). The rotor rotation speed was 45,000 rpm. The sedimentation pattern was recorded by the Philpot-Svensson refractometric optical system. The experimental data were processed using the GetData Graph Digitizer program (vers. 2.24). Sedimentation coefficients $s$ were calculated from the velocity of the sedimentation boundary in the concentration range $c=0.0019-0.0147 \mathrm{~g} \cdot \mathrm{cm}^{-3}$. The concentration dependences of $s$ are satisfactorily described by the Gralen relationship

$$
1 / s=1 / s_{0}\left(1+k_{\mathrm{S}} c\right)
$$

where $s_{0}$ is the sedimentation constant and $k_{\mathrm{s}}$ is the sedimentation coefficient (Figure 1). The $k_{\mathrm{s}}$ values of the investigated stars were within $11-27 \mathrm{~cm}^{3} \mathrm{~g}^{-1}$. Table 1 lists the $s_{0}$ values.

Table 1. Hydrodynamic characteristics and molar masses of investigated polymer stars.

\begin{tabular}{ccccccc}
\hline Polymer & $\boldsymbol{s}_{\mathbf{0}}, \mathbf{S v}$ & $\boldsymbol{R}_{\mathbf{h}-\mathbf{D}}, \mathbf{n m}$ & $\overline{\boldsymbol{v}} \mathbf{~ c m}^{\mathbf{3}} \mathbf{g}^{\mathbf{- 1}}$ & $\boldsymbol{M}_{\mathbf{s D}}, \mathbf{g} \cdot \mathbf{m o l} \mathbf{- 1}$ & {$\left[\eta \mathbf{\eta}, \mathbf{c m}^{\mathbf{3}} \mathbf{g}^{\mathbf{- 1}}\right.$} & $\boldsymbol{d n} / \mathbf{d c}, \mathbf{c m}^{\mathbf{3}} \mathbf{g}^{-\mathbf{1}}$ \\
\hline CPh6-PEtOz & 2.7 & 3.5 & 0.843 & 23,000 & 13.6 & 0.088 \\
CPh6-PiPrOz & 3.6 & 3.3 & 0.890 & 20,000 & 12.1 & 0.073 \\
CPh6-PEtOx & 2.3 & 3.0 & 0.861 & 15,000 & 8.0 & 0.091 \\
CPh6-PiPrOx & 2.3 & 2.6 & 0.851 & 14,000 & 5.7 & 0.084 \\
\hline
\end{tabular}




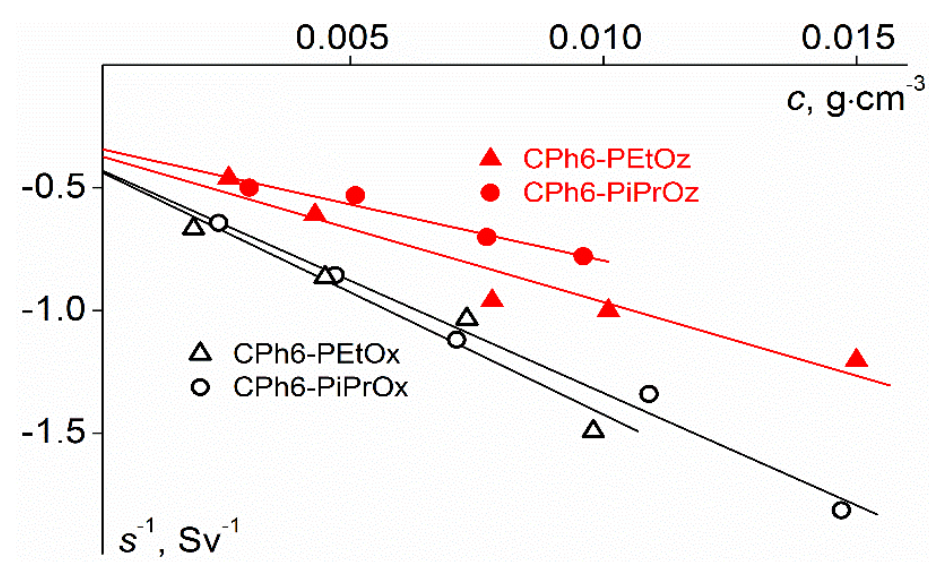

Figure 1. Concentration dependences of the inverse sedimentation coefficient $1 / s$ for the studied polymer stars in chloroform.

The hydrodynamic radii $R_{\mathrm{h}-\mathrm{D}}$ of macromolecules and the translational diffusion coefficients $D_{0}=k_{\mathrm{b}} T / 6 \pi \eta_{0} R_{\mathrm{h}-\mathrm{D}}$ were obtained by dynamic light scattering using the Photocor Complex (Photocor Instruments Inc., Moscow, Russia). The light source was the Photocor DL diode laser with a wavelength $\lambda=658.7 \mathrm{~nm}$. The correlation function of the scattered light intensity was obtained using the Photocor-PC2 correlator with the channel number of 288 and processed using DynalS software (ver. 8.2.3, SoftScientific, Tirat Carmel, Israel). Figure 2 shows the dependences of hydrodynamic radii $R_{\mathrm{h}-\mathrm{D}}(c)$ obtained at concentration $c$. The change in $R_{\mathrm{h}-\mathrm{D}}(c)$ reflects the concentration dependence of the diffusion constant $\mathrm{D}$. Extrapolation of $R_{\mathrm{h}-\mathrm{D}}(c)$ to $c=0$ yields the hydrodynamic radius $R_{\mathrm{h}-\mathrm{D}}$ of the macromolecules (Table 1).



Figure 2. Plots of $R_{\mathrm{h}-\mathrm{D}}(c)$ vs. concentration $c$ for the studied polymer stars in chloroform.

The so-called hydrodynamic molecular masses $M_{\mathrm{sD}}$ for CPh6-PAlOx and CPh6-PAlOz were calculated using the Svedberg equation:

$$
M_{\mathrm{SD}}=\frac{R T}{1-\bar{v} \rho} \frac{s_{0}}{D_{0}}
$$

where $R$ is the universal gas constant and $T$ is the absolute temperature. The specific partial volume $\bar{v}$ was determined using a densitometer (Density/Specific Gravity Meter DA-640, KEM, Tokyo, Japan). The values of $\bar{v}$ for investigated stars differed slightly (Table 1 ). The obtained values of $\bar{v}$ for the CPh6-PEtOx are close to those reported in the literature for linear PEtOx, to reported values from Schubert and Nischang et al. [26] of $\bar{v}=0.84 \mathrm{~cm}^{3} \mathrm{~g}^{-1}$, from Ye et al. [42] of $\bar{v}=0.85 \mathrm{~cm}^{3} \mathrm{~g}^{-1}$, and $\bar{v}=0.87 \mathrm{~cm}^{3} \mathrm{~g}^{-1}$ from Chen et al. [43]. In addition, the specific partial volumes for CPh6-PAlOx 
are in good agreement with the values of $\bar{v}$ for star-shaped PEtOx and PiPrOx [44-46]. MMs calculated by the relation (2) are shown in Table 1, which also gives the values of intrinsic viscosity [ $\eta$. The intrinsic viscosity was measured with the Ostwald-type Cannon-Manning capillary viscometer (Cannon Instrument Company Inc., State College, PA, USA) at $21^{\circ} \mathrm{C}$. The solvent efflux time was $48.5 \mathrm{~s}$. Figure 3 shows reduced viscosity $\eta_{\mathrm{sp}} / c$ versus concentration for solutions of synthesized stars. These dependences were analyzed using the Huggins equation

$$
\eta_{\mathrm{sp}} / c=[\eta]+k^{\prime}[\eta]^{2} c
$$

where $k^{\prime}$ is the Huggins constant characterizing the polymer-solvent hydrodynamic interaction and the hydrodynamic behavior of solutions [47-49]. In most cases, the Huggins constants turned out to be high $\left(k^{\prime}>0.5\right)$. The increased values of $k^{\prime}$ were found for polymer brushes, hyperbranched and star-shaped polymers [50-54]. It is possible that this phenomenon is typical for solutions of compact symmetric particles. For star-shaped CPh6-PAlOx and CPh6-PAlOz parameter $\gamma=k_{\mathrm{s}} /[\eta]$ is appreciably above $\gamma=1.7$, a value that is typical for linear flexible-chain polymers in good solvents $[47,55]$. Interestingly, the $\gamma$ value increases with the increase in intramolecular density. In fact, for rigid-chain polymers, parameter $\gamma$ is markedly lower than 1.7, sometimes by almost an order of magnitude [47].

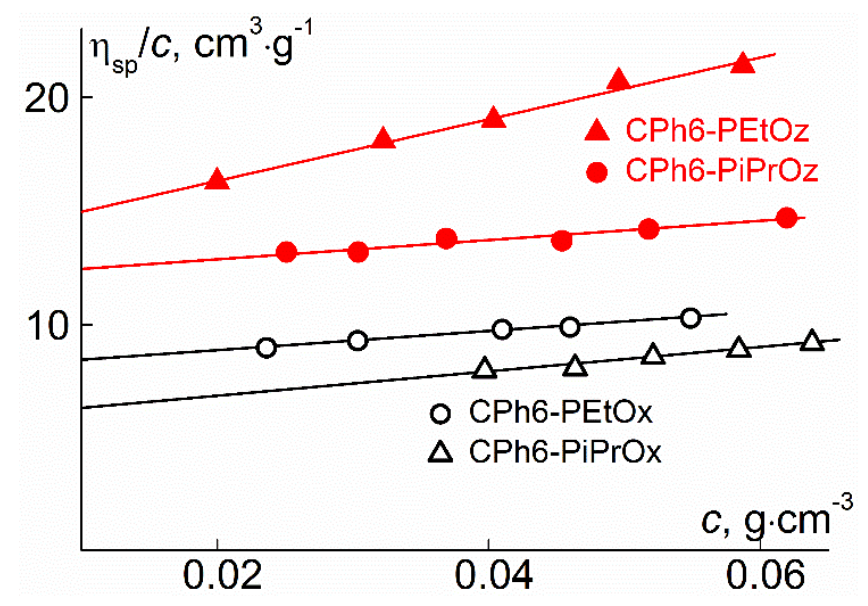

Figure 3. Reduced viscosity $\eta_{\mathrm{sp}} / c$ vs. $c$ for the studied polymer stars in chloroform.

The refractive index increment $d n / d c$ was determined using the RA-620 refractometer (KEM, Japan). The index $d n / d c$ for CPh6-PAlOx is similar to that for star-shaped PEtOx and PiPrOx with another structure of core $[20,46]$. Note that the refractive index increments for CPh6-PAlOx are higher than $d n / d c$ for their axozine analogs. Besides, the $d n / d c$ values decrease on passage from polymers with ethyl side groups to stars containing isopropyl.

The LCST behavior of the synthesized samples in water was studied by turbidimetry using the Photocor Complex. Measurements were carried out at the concentration $c=0.0015 \mathrm{~g} \cdot \mathrm{cm}^{-3}$. The experiments were performed in the temperature range from 15 to $75^{\circ} \mathrm{C}$. The temperature was changed discretely with a step from 0.5 to $5^{\circ} \mathrm{C}$ and regulated with the precision of $0.1{ }^{\circ} \mathrm{C}$.

\section{Results and Discussion}

\subsection{Polymer Synthesis And Structural Characteristics}

The parent ((2R, 3R, 12R, 13R, 22R, 23R)-1,4,11,14,21,24-Hexaaza-(2,3:12,13:22,23)-tributeno-(6,9:16, 19:26,29) - trietheno - 2H,3H,12H,22H,23H- (30)) -annulene (1), known under the trivial name of "trianglamine", was obtained by the well-known method [56] cyclocondensation of terephthalic aldehyde with (1R, 2R)-trans-diaminocyclohexane followed by the Schiff base reduction with sodium borohydride (Figure 4). Acylation of the resulting hexamine with 11-bromundecanoyl chloride in the 
presence of caesium carbonate leads to the corresponding hexamide formation, which was used as a macrocyclic initiator of the cationic polymerization of 2-alkyl-2-oxazolines and 2-alkyl-2-oxazines.
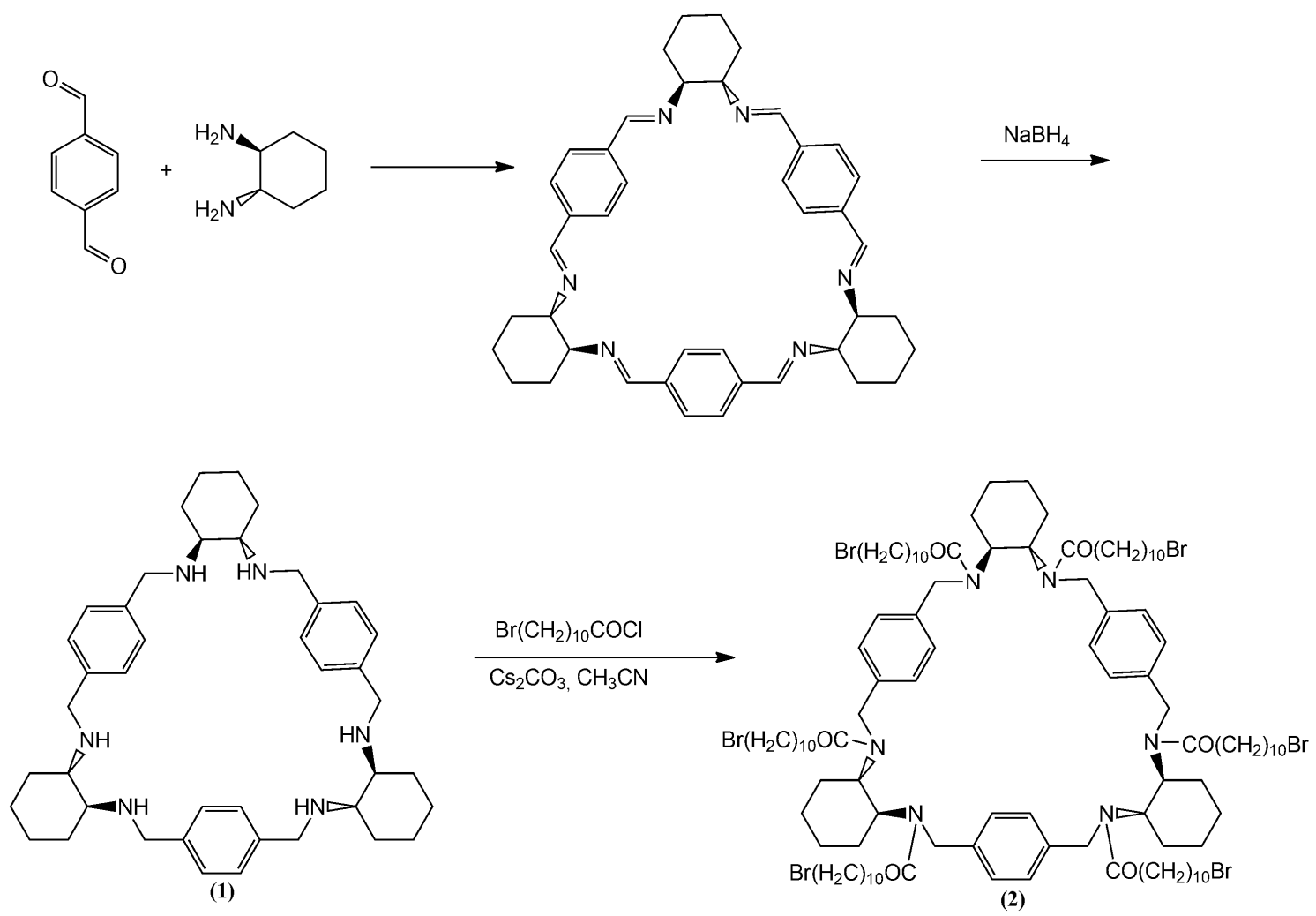

Figure 4. Scheme of synthesize of multicenter initiator.

It should be noted that other amidation procedures, in particular using different tertiary amines as bases (pyridine, triethylamine, 4-dimethylaminopyridine) led to incomplete acylation of cyclophane, which is probably the result of non-covalent interactions of the acceptor and the macrocycle. CROP was performed using the method developed by the authors for the synthesis of star-shaped poly-2-alkyl-2-oxazolines [57] and poly-2-alkyl-2-oxazines [36,40] with the calixarene core. It was found that the most suitable solvent for polymerization using abovementioned initiators is sulfolan. The synthesis scheme for CPh6-PAlOx and CPh6-PAlOz is shown in Figure 5.

Unfortunately, there are no effective procedures that give the possibility to achieve the selective cleavage of amide bond between the core and arms without destruction the very similar amide moieties in polyoxazoline fragments in the polymers under investigation. In order to verify the number of the arms we used the well-known approach based on correlation between molecular mass and hydrodynamic radii of star shaped polymers [58]. In Figure 6, the chromatograms of the star-shaped $\mathrm{CPh} 6-\mathrm{PAlOx}$ and $\mathrm{CPh} 6-\mathrm{PAlOz}$ are given. Monomodality and symmetrical form of the curve indicates the uniform structure of the polymers. In addition, all SEC traces have symmetrical forms that indicate the absence in the samples both higher- molecular and lower- molecular fractions. This suggests that the overwhelming number of $\mathrm{CPh} 6$-PAlOx and $\mathrm{CPh} 6-\mathrm{PAlOz}$ under investigation have six arms while the number of "defective" five-arms as well as four-arms molecules is small.

The difference in the MMs of oxazoline and oxazine stars results in the difference in the content of hydrophobic groups $\omega$ in their macromolecules (Table 2). In the studied polymers, the hydrophobic components include the $\mathrm{CPh} 6$ core and $-\left(\mathrm{CH}_{2}\right)_{10}$ - chains. For CPh6-PAlOx, the $\omega$ value is about $11 \mathrm{~mol} \%$, that is almost three times lower than $\omega$ for star-shaped PiPrOx with the carbosilane dendrimer as the core [46]. For PAlOx with calix[n]arene core, depending on the arm length, the molar fraction of hydrophobic groups is either close to or higher than the $\omega$ value for CPh6-PiPrOx [30,44]. CPh6-PAlOz 
are characterized by very low $\omega$ values, which are noticeably lower than $\omega=28 \mathrm{~mol} \%$ for four-beam $\mathrm{PEtOz}$ with calix[4]arene core [40].


b

C

d

Figure 5. Scheme of synthesize of star-shaped six-arm CPh6-PEtOz (a), CPh6-PiPrOz (b), CPh6-PEtOx (c), and CPh6-PiPrOx (d).

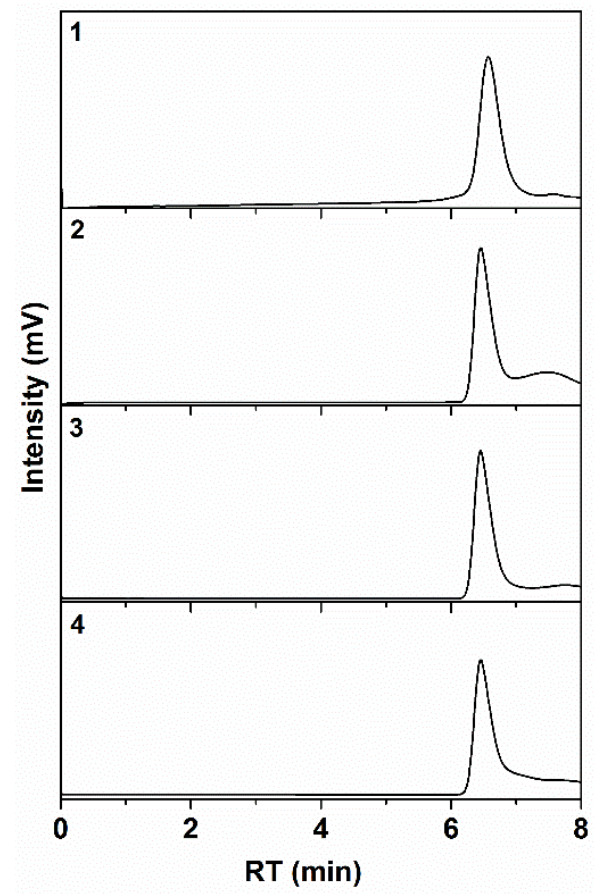

Figure 6. GPC curves of star-shaped CPh6-PEtOx (1), CPh6-PiPrOx (2), CPh6-PEtOz (3), and CPh6-PiPrOz (4).

The discussed differences in $\omega$ values are due to the structure of the branching center and the arm length. CPh6-PAlOx and CPh6-PAlOz have a relatively low core $\mathrm{MM}\left(M_{\text {core }}=810 \mathrm{~g} \cdot \mathrm{mol}^{-1}\right)$, while $M_{\text {core }}=1310$ and $9048 \mathrm{~g} \cdot \mathrm{mol}^{-1}$ for calix[8]arene and the second-generation carbosilane dendrimer, respectively. As for the $L_{\text {arm }}$ arm length, it is close or greater for the studied polymers than the $L_{\text {arm }}$ of the 
star-shaped PAlOx and PAlOz with calix[n]arene or dendrimer core $[30,40,44,46]$. The polymerization degree $N_{\mathrm{tsc}}$ of the thermosensitive chains for CPh6-PAlOx and CPh6-PAlOz was calculated by the ratio:

$$
N_{\mathrm{tsc}}=\left(M_{\mathrm{sD}}-M_{\mathrm{core}}-6 \cdot M_{\mathrm{alk}}\right) / 6 M_{0}
$$

where $M_{0}$ is the $\mathrm{MM}$ of PAlOx and PAlOz monomer units and $M_{\text {alk }}=140 \mathrm{~g} \cdot \mathrm{mol}^{-1}$ is the $\mathrm{MM}$ of alkylene chains. The lengths $L_{\mathrm{tsc}}$ of the thermosensitive chains and $L_{\mathrm{arm}}$ of the arms were calculated under the assumption that all valence bonds have the same length of $0.14 \mathrm{~nm}$, and the valence angles are tetrahedral. Then the length of the monomer unit is $\lambda_{0}=0.378 \mathrm{~nm}$ for PAlOx and $0.504 \mathrm{~nm}$ for PAlOz, and the length of the $-\left(\mathrm{CH}_{2}\right)_{10}$ - chain is $1.26 \mathrm{~nm}$. Table 2 shows that the PiPrOx and PEtOx chains are almost two times smaller than $L_{\mathrm{tsc}}$ for PiPrOz and PEtOz, respectively. Notably, in both pairs of stars the length of the PiPrOx and PiPrOz chains is less than the length of the PEtOx and PEtOz chains.

Table 2. Molar masses and structure characteristics of synthesized polymer stars.

\begin{tabular}{|c|c|c|c|c|c|c|}
\hline Polymer & $M_{\mathrm{sD}}, \mathrm{g} \cdot \mathrm{mol}^{-1}$ & $\omega, \operatorname{mol} \%$ & $M_{0}, \mathrm{~g} \cdot \mathrm{mol}^{-1}$ & $N_{\text {tsc }}$ & $L_{\mathrm{tsc}}, \mathrm{nm}$ & $L_{\mathrm{arm}}, \mathrm{nm}$ \\
\hline CPh6-PEtOz & 23,000 & 7.2 & 113 & 31 & 15.9 & 17.1 \\
\hline CPh6-PiPrOz & 20,000 & 8.3 & 127 & 24 & 12.1 & 13.4 \\
\hline CPh6-PEtOx & 15,000 & 11.0 & 99 & 22 & 8.5 & 9.8 \\
\hline CPh6-PiPrOx & 14,000 & 11.8 & 113 & 18 & 6.9 & 8.1 \\
\hline
\end{tabular}

\subsection{Hydrodynamic Characteristics And Conformation of CPh6-PAlOx And CPh6-PAlOz Macromolecules}

For all the polymers studied, the arm length $L_{\text {arm }}$ is much larger than the hydrodynamic radius of their macromolecules (Tables 2 and 3). The $L_{\mathrm{arm}} / R_{\mathrm{h}-\mathrm{D}}$ ratio ranges from 3.2 to 4.9 . These facts are sufficient to indicate that the macromolecules are compact, and the arms are quite strongly folded. More rigorous conclusions about the conformation of CPh6-PAlOx and $\mathrm{CPh} 6-\mathrm{PAlOz}$ macromolecules can be made by comparing their hydrodynamic characteristics with the data for linear PAlOx. (Unfortunately, we are not aware of any works devoted to the study of the hydrodynamic and conformational properties of PAlOz.)

Table 3. Hydrodynamic characteristics of investigated polymer stars.

\begin{tabular}{|c|c|c|c|}
\hline Polymer & $L_{a r m} / R_{h-D}$ & $L_{\text {arm }} / A_{\text {PEtOx }}$ & $A_{0} \cdot 10^{10}, \mathrm{erg} \cdot \mathrm{K}^{-1} \mathrm{~mol}^{-1 / 3}$ \\
\hline CPh6-PEtOz & 4.9 & 11 & 3.3 \\
\hline CPh6-PiPrOz & 3.8 & 8 & 3.2 \\
\hline CPh6-PEtOx & 3.3 & 6 & 2.8 \\
\hline CPh6-PiPrOx & 3.2 & 5 & 2.8 \\
\hline
\end{tabular}

In Figure 7, the values of characteristic viscosity [ $\eta]$ for the studied polymer stars are plotted as a function of MM. Additionally shown are the Mark-Kun-Hauwink-Sakurada (MKHS) dependences for linear PEtOx [26,59] and poly-2-methyl-2-oxazoline (PMeOx) [26], studied in thermodynamically good solvents. It is clearly seen that the points corresponding to [ $\eta$ ] for $\mathrm{CPh} 6-\mathrm{PAlOx}$ and $\mathrm{CPh} 6-\mathrm{PAlOz}$ lie significantly lower than the straight lines for PEtOx and PMeOx. On the other hand, they are grouped around the MKHS dependence for eight-arm polystyrene with calix[8]arene core (C8A-PS) [53]. Low values of $[\eta]$ indicate high intramolecular density of $\mathrm{CPh}$-PAlOx and $\mathrm{CPh} 6-\mathrm{PAlOz}$.

A similar conclusion can be made by comparing the molar mass dependences of the hydrodynamic radii $R_{\mathrm{h}}$ (Figure 8). For the studied CPh6-PAlOx and CPh6-PAlOz, the values of $R_{\mathrm{h}-\mathrm{D}}$ are slightly less than $R_{\mathrm{h}}$ for linear PEtOx and are close to the hydrodynamic radius of C8A-PS molecules. The difference in $R_{\mathrm{h}}$ for the compared polymers is noticeably smaller than in the case of intrinsic viscosity. This is due to the lower sensitivity of the $R_{\mathrm{h}}$ value to the change in the shape of the molecules and the molar mass of the polymer compared to the [ $\eta$ ] value [47]. 


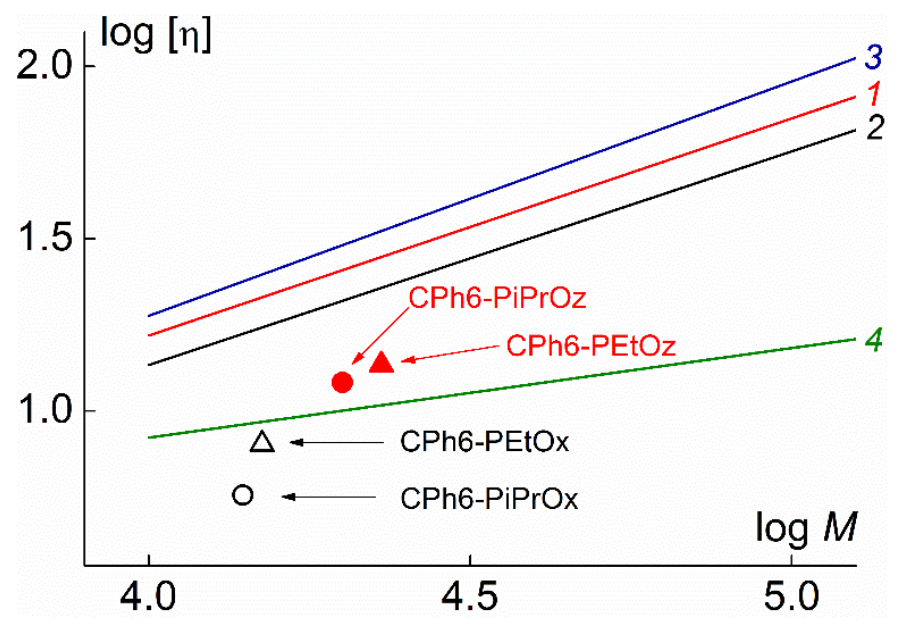

Figure 7. Intrinsic viscosity [ $\eta$ ] vs. molar mass $M$ for the studied polymer stars in chloroform and MKHS dependences for linear PEtOx (1 [26] and 2 [59]), PMeOx (3 [26]), and star-shaped eight-arm C8A-PS (4 [53]).

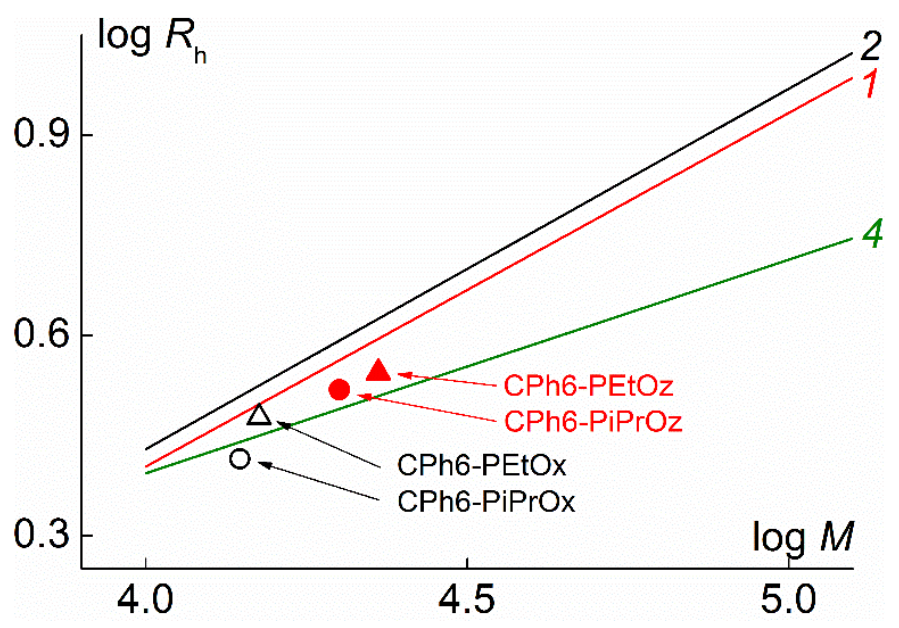

Figure 8. Hydrodynamic radius $R_{\mathrm{h}}$ vs. $M$ for the studied polymer stars in chloroform and MKHS dependences for linear PEtOx (1 [26] and 2 [59]) and star-shaped eight-arm C8A-PS (4 [53]).

To analyze the architecture dependence obtained from the experimental data, the so-called contraction factors, i.e., the rations of conformational and hydrodynamic parameters of the branched polymer to that of the linear polymer having the same molar mass are usually employed. Contraction factors are (i) ratio of the squared gyration radii $R_{g}$ :

$$
g=\left(R_{g}\right)_{b r}{ }^{2} /\left(R_{g}\right)_{l i n}{ }^{2}
$$

(ii) ratio of the intrinsic viscosities:

$$
g^{\prime}=[\eta]_{b r} /[\eta]_{l i n}
$$

(iii) ratio of the hydrodynamic radii:

$$
h=\left(R_{h}\right)_{b r} /\left(R_{h}\right)_{l i n}
$$

The subscript characters "br" and "lin" in Equations (5)-(7) mean that the parameter refers to the branched and linear polymer, respectively.

Unfortunately, the geration radii $R_{\mathrm{g}}$ for $\mathrm{CPh} 6-\mathrm{PAlOx}$ and $\mathrm{CPh} 6-\mathrm{PAlOz}$ could not be experimentally measured due to the small size of the macromolecules. The $g^{\prime}$ and $h$ values are shown in Table 4 . They were determined using the MKHS dependences for linear PEtOx [26,59]. The number on the left 
in each cell of Table 4 was calculated by comparing the characteristics of CPh6-PAlOx and CPh6-PAlOz with the data obtained by Filippov and Hoogenboom [59]. To determine the values in the cells on the right, we used the dependences [ $\eta$ ] and $R_{\mathrm{h}}$ on MM, established by Schubert and Nischang [26]. As can be seen from Table 4, the contraction factors for polyoxazoline stars are smaller than $g^{\prime}$ and $h$ for CPh6-PAlOz.

Table 4. Contraction factors for investigated polymer stars.

\begin{tabular}{cccccc}
\hline Polymer & $g^{\prime}$ & $h$ & $g_{\eta}$ & $g_{h}$ & $L_{\text {arm }} / A_{\text {PEtOx }}$ \\
\hline CPh6-PEtOz & $0.60 / 0.49$ & $0.88 / 0.94$ & $0.51 / 0.41$ & $0.58 / 0.74$ & 11 \\
CPh6-PiPrOz & $0.58 / 0.47$ & $0.87 / 0.93$ & $0.49 / 0.39$ & $0.57 / 0.71$ & 8 \\
CPh6-PEtOx & $0.38 / 0.46$ & $0.81 / 0.86$ & $0.31 / 0.38$ & $0.44 / 0.54$ & 6 \\
CPh6-PiPrOx & $0.28 / 0.34$ & $0.71 / 0.76$ & $0.22 / 0.27$ & $0.29 / 0.36$ & 5 \\
\hline
\end{tabular}

Note that we analyze the contraction factors by comparing the hydrodynamic characteristics of all the studied stars with the data for PEtOx. Therefore, the "true" values of $g^{\prime}$ and $h$ are obtained only for CPh6-PEtOx. For the remaining polymers, $g^{\prime}$ and $h$ shown in Table 4 will slightly differ from the values which could be obtained using the values [ $\eta$ ] and $R_{\mathrm{h}}$ for linear PiPrOx, PiPrOz, and PEtOz to determine them. It can be expected that the differences in $[\eta]$ and $R_{\mathrm{h}}$ for the linear polypeptoids under consideration are small. Compared to PEtOx, the side chains of PiPrOx and PiPrOz contain one $-\mathrm{CH}_{3}$ group more, and the monomer units of $\mathrm{PAlOz}$ are longer by $-\mathrm{CH}_{2}-$ group. Obviously, the increase in the size of the side chain should be accompanied by an increase in $[\eta]$ and $R_{\mathrm{h}}$, and elongation of the monomer unit of the flexible main chain can cause a decrease in these parameters. However, systematic studies of various classes of comb-shaped polymers [47] showed that, at the described structural variations, the hydrodynamic and conformational characteristics of polymers practically do not change. For example, for polymers with short side chains containing less than six bonds, the considered changes fall within the experimental error [47]. Therefore, the values of $g^{\prime}$ and $h$ given in Table 4 for $\mathrm{CPh} 6-\mathrm{PiPrOx}, \mathrm{CPh} 6-\mathrm{PiPrOz}$, and $\mathrm{CPh}$ - $\mathrm{PEtOz}$ can serve as a reliable quantitative characteristic of these polymers.

Probably, Zimm and Kilb made the first attempt to find a relationship between $g$ and $g^{\prime}$ for star polymers [60]. Using the Kirkwood-Riseman approximation for the hydrodynamic interaction, they concluded that $g^{\prime}=g^{1 / 2}$. However, such behavior has not been observed experimentally [61], and Kurata with coauthors established empirically that $g^{\prime}=g^{0.6}$ [62]. Later Weissmuller and Burchard [63] showed that dependence of $g^{\prime}$ on $g$ cannot be described by a power law, and after analyzing the experimental data for a large number of polymer stars with various structures, they proposed the equation:

$$
g^{\prime}=\left(1.104-0.104 g^{7}\right) g^{0.906}
$$

Stockmayer and Fixman [64] assumed that for diffusion $h$ and viscosity $g^{\prime}$ contraction factors are related by the formula:

$$
g^{\prime}=h^{3}
$$

Using the above equations, we calculated the values of the contraction factor for the studied polymer stars from the data of rotational $\left(g_{\eta}\right.$, Equation (8)) and translational $\left(g_{\mathrm{h}}\right.$, a combination of Equations (8) and (9)) friction (Table 4). Similar to $g^{\prime}$ and $h$, the compression factors $g_{\eta}$ and $g_{\mathrm{h}}$ are lower for CPh6-PAlOx than for CPh6-PAlOz. The values of $g_{\eta}$ and $g_{\mathrm{h}}$ obtained for the studied polymers can be compared with the theoretically predicted $g$. For star-shaped polymers with very long monodisperse arms, Zimm and Stockmayer obtained [65]:

$$
g=\left(3 f_{a}-2\right) / f_{a}^{2}
$$


where $f_{\mathrm{a}}$ is the arm number. Accordingly, for six-pointed stars, $g=0.44$. For stars with polydisperse arms [66,67], the relation is

$$
g=3 f_{a} /\left(f_{a}+1\right)^{2}
$$

that is, for a star with six arms, $g=0.37$. From Daoud-Cotton theory, we can get [68]

$$
g=f_{a}^{-4 / 5}
$$

therefore, for six-arm stars, $g=0.24$.

The contraction factor $g_{\eta}$, determined from the values of intrinsic viscosity, for a star with the shortest arm, corresponds to the conclusions based on the Daoud-Cotton theory. For other polymers, $g_{\eta}$ are close to the $g$ values for star-shaped macromolecules with long arms. The Kuhn segment length $A_{\text {PEtOx }}$ for linear PEtOz is $1.4-1.8 \mathrm{~nm}[59,69]$. Therefore, taking into account the above comments on the hydrodynamic and conformational characteristics of polypeptoids, it can be assumed that the studied polymer stars can be considered as long-arm stars, if the arms contain six or more Kuhn segments. As for the contraction factor obtained using translational friction data, for all polymers except CPh6-PiPrOx $g_{\mathrm{h}}$ exceeds theoretically predicted the $g$ values. This discrepancy can be explained by the fact that when calculating $g_{\mathrm{h}}$ twice (both in Equation (8) and Equation (9)), the Gaussian chain approximation is used. In addition, a large experimental error should be taken into account when determining the hydrodynamic radii of macromolecules.

An important characteristic of the macromolecule behavior in solutions is the so-called hydrodynamic invariant $[47,70,71]$ :

$$
A_{0} \equiv \eta_{0}\left(\frac{D_{0}}{T}\right)^{2 / 3}\left[\frac{[\eta] s_{0} R}{100\left(1-\bar{v} \rho_{0}\right)}\right]^{1 / 3}
$$

For linear macromolecules, $A_{0}$ is constant over a wide MM region: the average experimental values are $A_{0}=3.2 \cdot \times 10^{-10} \mathrm{erg} \cdot \mathrm{K}^{-1} \mathrm{~mol}^{-1 / 3}$ for flexible chain and $3.8 \times 10^{-10} \mathrm{erg} \cdot \mathrm{K}^{-1} \mathrm{~mol}^{-1 / 3}$ for rigid chain polymers $[47,70]$. These are in good agreement with the theoretical values $A_{0}$ obtained using various methods for considering the hydrodynamic interaction and using different statistical models of linear macromolecules [47,70]. Hyperbranched polymers and dendrimers are often characterized by very low, up to $A_{0}=2 \times \cdot 10^{-10} \mathrm{erg} \cdot \mathrm{K}^{-1} \mathrm{~mol}^{-1 / 3}$, values of the hydrodynamic invariant [50,72]. For linear $\mathrm{PEtOz}$, the typical value for flexible chain polymers is $A_{0}=3.45 \cdot \times 10^{-10} \mathrm{erg} \cdot \mathrm{K}^{-1} \mathrm{~mol}^{-1 / 3}$ [26].

As can be seen from Table $3, A_{0}$ for CPh6-PAlOz are in good agreement with the experimental values of the hydrodynamic invariant for flexible chain polymers. For stars, CPh6-PAlOx $A_{0}$ is noticeably lower; it is close to the theoretical value for impermeable hard spheres $2.88 \cdot \times 10^{-10} \mathrm{erg} \cdot \mathrm{K}^{-1}$ $\mathrm{mol}^{-1 / 3}$. It can be assumed that this difference is due to different arm lengths in CPh6-PAlOx and CPh6-PAlOz molecules.

\subsection{LCST Behavior of CPh6-PAlOx And CPh6-PAlOz}

All synthesized stars exhibit LCST behavior, as illustrated in Figure 9. The cloud point temperature $T_{\mathrm{cp}}$ is defined as the beginning of the decline in optical transmittance. In both ranks $T_{\mathrm{cp}}$ for stars with isopropyl groups in the side chains of arms, lower than for polymers with ethyl groups. This behavior is in qualitative agreement with what is observed for linear PAlOx and PAlOz [35,73-75]. As in the case of linear polypeptoids, elongation of the monomer unit leads to a decrease in $T_{\mathrm{cp}}$ : the difference in $T_{\mathrm{cp}}$ is about $11{ }^{\circ} \mathrm{C}$ for the pair CPh6-PiPrOx and CPh6-PiPrOz and $9{ }^{\circ} \mathrm{C}$ for CPh6-PEtOx and CPh6-PEtOz. However, in this comparison, it should be taken into account that $\mathrm{MM} \mathrm{CPh6-PAlOz} \mathrm{is} \mathrm{noticeably} \mathrm{higher}$ than MM CPh6-PAlOx, which can also lead to a decrease in the cloud point. As for the absolute values of $T_{\mathrm{cp}}$, for CPh6-PAlOx they are in agreement with the data for the star-shaped four- and eight-arm PAlOx with calix[n]arenes and carbosilane dendrimers as the core $[20,28,46,76]$. 


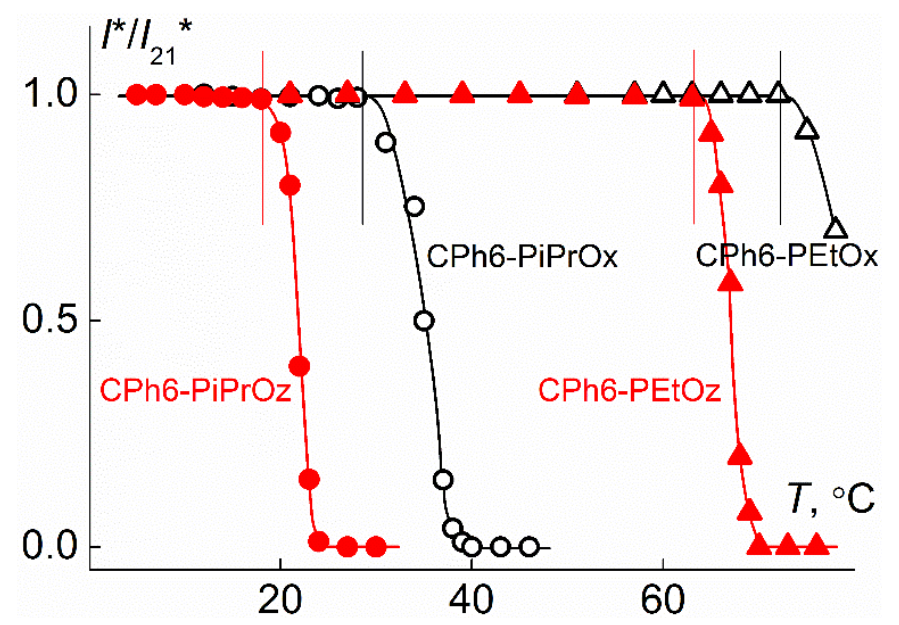

Figure 9. Dependences of relative transmittance $I^{*} / I_{21}$ for aqueous solutions of studied polymer stars. $I_{21} *$ is intensity of optical transmittance at $T=21^{\circ} \mathrm{C}$.

\section{Conclusions}

For the first time, star-shaped six-arm polypeptoids, namely, poly-2-alkyl-2-oxazine and poly-2-alkyl-2-oxazoline were synthesized successfully using cationic ring-opening polymerization. The derivative of hexaaza[2 ${ }_{6}$ ]orthoparacyclophane with long enough undecenyl spacers was used as macroinitiators in core-first synthesis. NMR spectroscopy and chromatography confirmed the structure prepared samples and showed practically simultaneous polymerization of the arms on the initiation centers.

Using the methods of molecular hydrodynamics and optics, it was established that the arm structure does not affect practically the conformation of star-shaped macromolecules of studied polypeptoids. Much more important is the length of the arms, elongation of which leads to an increase in contraction factors. This behavior is explained by the close equilibrium rigidity of the polymers used as arms. The polymer stars under investigation are the long-arm stars, if the arms contain six or more Kuhn segments. On the one hand, the PAlOz and PalOx arms are folded, and star-chaped CPh6-PAlOz and CPh6-PAlOx are characterized by elevated intramolecular density in comparizing with their linear analogs. Changes in the conformational and hydrodynamic behavior of the studied polymer stars with decreasing of arm lengths are indicated by a decrease in the values of the hydrodynamic invariant.

The synthesized stars were thermosensitive exhibiting LCST behavior. At the passage from CPh6-PAlOx to CPh6-PAlOz, a decrease in the temperature of phase separation is observed, which is in accordance with the behavior of linear analogs. The cloud point temperature for CPh6-PEtOz is higher than the $T_{\mathrm{cp}}$ value for its structural isomer $\mathrm{CPh}$-PiPrOx.

Supplementary Materials: The following are available online at http://www.mdpi.com/2073-4360/12/4/800/s1, Figure S1. 1H NMR spectrum of trianglamine; Figure S2. 1H NMR spectra of star-shaped poly(2-ethyl-2-oxazoline) (1), poly(2-isopropyl-2-oxazoline) (2), poly(2-ethyl-2-oxazine) (3), and poly(2-isopropyl-2-oxazine) (4). Solvent - d-chlorophorm.

Author Contributions: Conceptualization, A.F.; methodology, A.T.; writing-original draft preparation, A.T., A.F. and T.K.; formal analysis, A.T and T.K.; investigation, T.K., A.R. and A.S.; resources, A.S.; data curation, A.S.; writing-review and editing, A.S. and A.R.; visualization, T.K.; supervision, A.F.; project administration, A.F.; funding acquisition, T.K. All authors have read and agreed to the published version of the manuscript.

Funding: This research was funded by the Russian Science Foundation, grant number 19-73-00175.

Conflicts of Interest: The authors declare no conflict of interest. 


\section{References}

1. Wang, F.; Bronich, T.K.; Kabano, A.V.; Rauh, R.D.; Roovers, J. Synthesis and characterization of star poly( $\varepsilon$-caprolactone)-b-poly(ethylene glycol) and poly(L-lactide)-b-poly(ethylene glycol) copolymers: Evaluation as drug delivery carriers. Bioconjugate Chem. 2008, 19, 1423-1429. [CrossRef] [PubMed]

2. Wu, W.; Wang, W.; Li, J. Star polymers: Advances in biomedical applications. Prog. Polym. Sci. 2015, 46, 55-85. [CrossRef]

3. Lou, L.; Jiang, L.; Liu, J.; Sun, W.; Shen, Z. Synthesis and characterization of optically active star-shaped poly (N-phenylmaleimide)s with a calixarene core. Polym. Int. 2007, 56, 796-802. [CrossRef]

4. Terashima, T.; Kojima, H.; Sawamoto, M. Core-imprinted star polymers via living radical polymerization: Precision cavity microgels for selective molecular recognition. Chem. Lett. 2014, 43, 1690-1692. [CrossRef]

5. Granata, G.; Paterniti, I.; Geraci, C.; Cunsolo, F.; Esposito, E.; Cordaro, M.; Blanco, A.R.; Cuzzocrea, S.; Consoli, G.H.L. Potential eye drop based on a calix[4]arene nanoassembly for curcumin delivery: Enhanced drug solubility, stability, and antiInflammatory effect. Mol. Pharm. 2017, 14, 1610-1622. [CrossRef]

6. Drakalska, E.; Momekova, D.; Manolova, Y.; Budurova, D.; Momekov, G.; Genova, M.; Antonov, L.; Lambov, N.; Rangelov, S. Hybrid liposomal PEGylated calix[4]arene systems as drug delivery platforms for curcumin. Int. J. Pharm. 2014, 472, 165-174. [CrossRef]

7. Guillerm, B.; Monge, S.; Lapinte, V.; Robin, J.-J. Novel investigations on kinetics and polymerization mechanism of oxazolines initiated by iodine. Macromolecules 2010, 43, 5964-5970. [CrossRef]

8. Obeid, R.; Maltseva, E.; Thunemann, A.F.; Tanaka, F.; Winnik, F.M. Temperature response of self-assembled micelles of telechelic hydrophobically modified poly(2-alkyl-2-oxazoline)s in water. Macromolecules 2009, 42, 2204-2214. [CrossRef]

9. Borisova, N.E.; Reshetova, M.D.; Ustynyuk, Y.A. Metal-free methods in the synthesis of macrocyclic schiff bases. Chem. Rev. 2007, 107, 46-79. [CrossRef]

10. Gajewy, J.; Szymkowiak, J.; Kwit, M. Fine tuning of molecular and supramolecular properties of simple trianglimines-The role of the functional group. Rsc Adv. 2016, 6, 53358-53369. [CrossRef]

11. Gawronski, J.; Gawronska, K.; Grajewski, J.; Kwit, M.; Plutecka, A.; Rychlewska, U. Trianglamines—Readily prepared, conformationally flexible inclusion forming chiral hexamines. Chem. Eur. J. 2006, 12, 1807-1817. [CrossRef] [PubMed]

12. Gualandi, A.; Grilli, S.; Savoia, D.; Kwit, M.; Gawronski, J. C-hexaphenyl-substituted trianglamine as a chiral solvating agent for carboxylic acids. Org. Biomol. Chem. 2011, 9, 4234-4241. [CrossRef] [PubMed]

13. Chaix, A.; Mouchaham, G.; Shkurenko, A.; Hoang, P.; Moosa, B.; Bhatt, P.M.; Adil, K.; Salama, K.N.; Eddaoudi, M.; Khashab, N.M. Trianglamine-based supramolecular organic framework with permanent intrinsic porosity and tunable selectivity. J. Am. Chem. Soc. 2018, 140, 14571-14575. [CrossRef] [PubMed]

14. Chu, Z.; Huang, W.; Wang, L.; Gou, S. Chiral 27-membered [3 + 3] schiff-base macrocycles and their reactivity with first-row transition metal ions. Polyhedron 2008, 27, 1079-1092. [CrossRef]

15. Tenkovtsev, A.V.; Dudkina, M.M.; Scherbinskaya, L.I.; Aseyev, V.; Tenhu, H. Star-shaped macromolecules with calixarene core and neutral amphiphilic block copolymer arms: New hosts for ions. Polymer 2010, 51, 3108-3115. [CrossRef]

16. Kempe, K. Chain and step growth polymerizations of cyclic imino ethers: From poly(2-oxazoline)s to poly(ester amide)s. Macromol. Chem. Phys. 2017, 218, 1700021. [CrossRef]

17. Park, J.-S.; Kataoka, K. Precise control of lower critical solution temperature of thermosensitive poly(2-isopropyl-2-oxazoline) via gradient copolymerization with 2-ethyl-2-oxazoline as a hydrophilic comonomer. Macromolecules 2006, 39, 6622-6630. [CrossRef]

18. Weber, C.; Wagner, M.; Baykal, D.; Hoeppener, S.; Paulus, R.M.; Festag, G.; Altuntas, E.; Schacher, F.H.; Schubert, U.S. Easy access to amphiphilic heterografted poly(2-oxazoline) comb copolymers. Macromolecules 2013, 46, 5107-5116. [CrossRef]

19. Luxenhofer, R.; Bezen, M.; Jordan, R. Kinetic investigations on the polymerization of 2-oxazolines using pluritriflate initators. Macromol. Rapid Commun. 2008, 29, 1509-1513. [CrossRef]

20. Tenkovtsev, A.V.; Amirova, A.I.; Filippov, A.P. Temperature-Responsive Polymers: Chemistry, Properties and Applications; Chapter 3; Khutoryanskiy, V., Georgiou, T., Eds.; John Wiley \& Sons: Hoboken, NJ, USA, 2018 ; p. 67.

21. Dworak, A.; Trzebicka, B.; Kowalczuk, A.; Tsvetanov, C.; Rangelov, S. Polyoxazolines-mechanism of synthesis and solution properties. Polymery 2014, 59, 88-94. [CrossRef] 
22. Glassner, M.; D’hooge, D.R.; Park, J.; Van Steenberge, P.H.; Monnery, B.D.; Reyniers, M.-F.; Hoogenboom, R. Systematic investigation of alkyl sulfonate initiators for the cationic ring-opening polymerization of 2-oxazolines revealing optimal combinations of monomers and initiators. Eur. Polym. J. 2015, 65, $298-304$. [CrossRef]

23. Glassner, M.; Vergaelen, M.; Hoogenboom, R. Poly(2-oxazoline)s: A comprehensive overview of polymer structures and their physical properties. Polym. Int. 2018, 67, 32-45. [CrossRef]

24. Oleszko-Torbus, N.; Wałach, W.; Utrata-Wesołek, A.; Dworak, A. Control of the crystalline properties of 2-isopropyl-2-oxazoline copolymers in condensed state and in solution depending on the composition. Macromolecules 2017, 50, 7636-7645. [CrossRef]

25. Hoogenboom, R.; Schlaad, H. Thermoresponsive poly(2-oxazoline)s, polypeptoids, and polypeptides. Polym. Chem. 2017, 8, 24-40. [CrossRef]

26. Grube, M.; Leiske, M.N.; Schubert, U.S.; Nischang, I. POx as an alternative to PEG? A hydrodynamic and light scattering study. Macromolecules 2018, 51, 1905-1916. [CrossRef]

27. Tu, C.; Zhu, L.; Li, P.; Chen, Y.; Su, Y.; Yan, D.; Zhu, X.; Zhou, G. Supramolecular polymeric micelles by the host-guest interaction of star-like calix[4]arene and chlorin e6 for photodynamic therapy. Chem. Commun. 2011, 47, 6063-6065. [CrossRef]

28. Kowalczuk, A.; Kronek, J.; Bosowska, K.; Trzebicka, B.; Dworak, A. Star poly(2-ethyl-2-oxazoline)s-Synthesis and thermosensitivity. Polym. Int. 2011, 60, 1001-1009. [CrossRef]

29. Amirova, A.I.; Golub, O.V.; Kirila, T.U.; Razina, A.B.; Tenkovtsev, A.V.; Filippov, A.P. Influence of arm length and number on star-shaped poly(2-isopropyl-2-oxazoline) aggregation in aqueous solutions near cloud point. Soft Mater. 2016, 14, 15-26. [CrossRef]

30. Amirova, A.; Golub, O.; Kirila, T.; Razina, A.; Tenkovtsev, A.; Filippov, A. Influence of arm length on aqueous solution behavior of thermosensitive poly(2-isopropyl-2-oxazoline) stars. Colloid Polym. Sci. 2017, 295, 117-124. [CrossRef]

31. Kobayashi, S.; Igarashi, T.; Moriuchi, Y.; Saegusa, T. Block copolymers from cyclic imino ethers: A new class of nonionic polymer surfactant. Macromolecules 1986, 19, 535-541. [CrossRef]

32. Bassiri, T.G.; Levy, A.; Litt, M. Polymerization of cyclic imino ethers. I. Oxazolines. J. Polym. Sci. B Polym. Lett. 1967, 5, 871-879. [CrossRef]

33. Bloksma, M.M.; Paulus, R.M.; van Kuringen, H.P.; van der Woerdt, F.; Lambermont-Thijs, H.M.; Schubert, U.S.; Hoogenboom, R. Thermoresponsive poly(2-oxazine)s. Macromol. Rapid Commun. 2012, 33, 92-96. [CrossRef] [PubMed]

34. Lambermont-Thijs, H.M.L.; Fijten, M.W.M.; van der Linden, A.J.T.; van Lankvelt, B.M.; Bloksma, M.M.; Schubert, U.S.; Hoogenboom, R. Efficient cationic ring-opening polymerization of diverse cyclic imino ethers: Unexpected copolymerization behavior. Macromolecules 2011, 44, 4320-4325. [CrossRef]

35. Sedlacek, O.; Hoogenboom, R. Drug delivery systems based on poly(2-oxazoline)s and poly(2-oxazine)s. Adv. Ther. 2019, 1900168. [CrossRef]

36. Kurlykin, M.P.; Dudkina, M.M.; Tenkovtsev, A.V. Star-shaped thermosensitive poly(2-ethyl-2-oxazines) with the calixarene core. Polym. Sci. B 2019, 61, 51-55. [CrossRef]

37. Giulia, M.; Verbraeken, B.; Ramakrishna, S.N.; Gombert, Y.; Cavalli, E.; Rosenboom, J.-G.; Zenobi-Wong, M.; Spencer, N.D.; Hoogenboom, R.; Benetti, E.M. Chemical design of non-ionic polymer brushes as biointerfaces: Poly(2-oxazine)s outperform both poly(2-oxazoline)s and PEG. Angew. Chem. Int. Ed. 2018, 57, 11667-11672.

38. Lübtow, M.M.; Hahn, L.; Haider, M.S.; Luxenhofer, R. Drug specificity, synergy and antagonism in ultrahigh capacity poly(2-oxazoline)/poly(2-oxazine) based formulations. J. Am. Chem. Soc. 2017, 139, 10980-10983. [CrossRef]

39. Bloksma, M.M.; Schubert, U.S.; Hoogenboom, R. Poly(cyclic imino ether)s beyond 2-substituted-2-oxazolines. Macromol. Rapid Commun. 2011, 32, 1419-1441. [CrossRef]

40. Kirila, T.U.; Smirnova, A.V.; Filippov, A.S.; Razina, A.B.; Tenkovtsev, A.V.; Filippov, A.P. Thermosensitive star-shaped poly-2-ethyl-2-oxazine. Synthesis, structure characterization, conformation, and self-organization in aqueous solutions. Eur. Polym. J. 2019, 120, 109215. [CrossRef]

41. Witte, H.; Seeliger, W. Cyclische imidsäureester aus nitrilen und aminoalkoholen. Justus Liebigs Ann. Chem. 1974, 6, 996-1009. [CrossRef]

42. Ye, X.D.; Yang, J.X.; Ambreen, J. Scaling laws between the hydrodynamic parameters and molecular weight of linear poly(2-ethyl-2-oxazoline). RSC Adv. 2013, 3, 15108-15113. [CrossRef] 
43. Chen, C.H.; Wilson, J.; Chen, W.; Davis, R.M.; Riffle, J.S. A light-scattering study of poly(2-alkyl-2-oxazoline)s: Effect of temperature and solvent type. Polymer 1994, 35, 3587-3591. [CrossRef]

44. Kirila, T.Y.; Kurlykin, M.P.; Tenkovtsev, A.V.; Filippov, A.P. Behavior of aqueous solutions of thermosensitive starlike polyalkyloxazolines with different arm structures. Polym. Sci. A 2017, 59, 826-838. [CrossRef]

45. Sezonenko, T.; Qiu, X.-P.; Winnik, F.M.; Sato, T. Dehydration, micellization, and phase separation of thermosensitive polyoxazoline star block copolymers in aqueous solution. Macromolecules 2019, 52, 935-944. [CrossRef]

46. Amirova, A.; Rodchenko, S.; Makhmudova, Z.; Cherkaev, G.; Milenin, S.; Tatarinova, E.; Kurlykin, M.; Tenkovtsev, A.; Filippov, A. Synthesis, characterization, and investigation of thermosensitive star-shaped poly(2-isopropyl-2-oxazolines) based on carbosilane dendrimers. Macromol. Chem. Phys. 2017, 218, 1600387. [CrossRef]

47. Tsvetkov, V.N. Rigid-Chain Polymers; Plenum: New York, NY, USA, 1989.

48. Rueb, C.J.; Zukoski, C.F. Rheology of suspensions of weakly attractive particles: Approach to gelation. J. Rheol. 1998, 42, 1451-1476. [CrossRef]

49. Yamakawa, H. Modern Theory of Polymer Solutions; Harper and Row: New York, NY, USA, 1971.

50. Filippov, A.P.; Belyaeva, E.V.; Tarabukina, E.B.; Amirova, A.I. Behavior of hyperbranched polymers in solutions. Polym. Sci. Ser. C 2011, 53, 107-117. [CrossRef]

51. Bodnár, I.; Silva, A.S.; Deitcher, R.W.; Weisman, N.E.; Kim, Y.H.; Wagner, N.J. Structure and rheology of hyperbranched and dendritic polymers. I. Modification and characterization of poly(propyleneimine) dendrimers with acetyl groups. J. Polym. Sci. Part B Polym. Phys. 2000, 38, 857-873.

52. Jeong, M.; Mackay, M.E.; Vestberg, R.; Hawker, C.J. Intrinsic viscosity variation in different solvents for dendrimers and their hybrid copolymers with linear polymers. Macromolecules 2001, 34, 4927-4936. [CrossRef]

53. Simonova, M.A.; Tarasova, E.V.; Dudkina, M.M.; Tenkovtsev, A.V.; Filippov, A.P. Synthesis and hydrodynamic and conformation properties of star-shaped polystyrene with calix[8]arene core. Int. J. Polym. Anal. Charact. 2019, 24, 87-95. [CrossRef]

54. Terao, K.; Hokajo, T.; Nakamura, Y.; Norisuye, T. Solution properties of polymacromonomers consisting of polystyrene. 3. Viscosity behavior in cyclohexane and toluene. Macromolecules 1999, 32, 3690-3694. [CrossRef]

55. Wales, M.; Rehfeld, S.J. Molecular weight distribution by velocity ultracentrifugation. J. Polym. Sci. 1962, 62, 179-196. [CrossRef]

56. Chadim, M.; Budesınsky, J.; Hodacova, J.; Zavada, P.C. Junk (3+3)-cyclocondensation of the enantiopure and racemic forms of trans-1,2-diaminocyclohexane with terephthaldehyde. Formation of diastereomeric molecular triangles and their stereoselective solid-state stacking into microporous chiral columns. Tetrahedron Asymmetry 2001, 12, 127-133. [CrossRef]

57. Ten'kovtsev, A.V.; Trofimov, A.E.; Shcherbinskaya, L.I. Thermoresponsive star-shaped poly(2-isopropyl-2-oxazolines) based on octa-tert-butylcalix[8]arene. Polym. Sci. Ser. B 2012, 54, 142-148. [CrossRef]

58. Plet, L.; Delecourt, G.; Hanafi, M.; Pantoustier, N.; Pembouong, G.; Midoux, P.; Bennevault, V.; Guégan, P. Controlled star poly(2-oxazoline)s: Synthesis, characterization. Eur. Polym. J. 2020, 122, 109323. [CrossRef]

59. Gubarev, A.S.; Monnery, B.D.; Lezov, A.A.; Sedlacek, O.; Tsvetkov, N.V.; Hoogenboom, R.; Filippov, S.K. Conformational properties of biocompatible poly(2-ethyl-2-oxazoline)s in phosphate buffered saline. Polym. Chem. 2018, 9, 2232-2237. [CrossRef]

60. Zimm, B.H.; Kilb, R.W. Dynamics of branched polymer molecules in dilute solution. J. Polym. Sci. 1959, 37, 19-42. [CrossRef]

61. Burchard, W. Solution properties of branched macromolecules. In Branched Polymers II; Roovers, J., Ed.; Springer: Berlin/Heidelberg, Germany, 1999; pp. 113-194.

62. Kurata, M.; Abe, M.; Iwama, M.; Matsushima, M. Randomly branched polymers. I. Hydrodynamic properties. Polym. J. 1972, 3, 729-738. [CrossRef]

63. Weissmuller, M.; Burchard, W. Molar mass distributions of end-linked polystyrene star macromolecules. Polym. Int. 1997, 44, 380-390. [CrossRef]

64. Stockmayer, W.H.; Fixman, M. Dilute solutions of branched polymers. Ann. N. Y. Acad. Sci. 1953, 57, 334-352. [CrossRef] 
65. Zimm, B.H.; Stockmayer, W.H. The Dimensions of Chain Molecules Containing Branches and Rings. J. Chem. Phys. 1949, 17, 1301-1314. [CrossRef]

66. Burchard, W. Particle scattering factors of some branched polymers. Macromolecules 1977, 10, 919-927. [CrossRef]

67. Burchard, W. Static and dynamic light scattering from branched polymers and biopolymers. Adv. Polym. Sci. 1983, 48, 1-124.

68. Daoud, M.; Cotton, J.P. Star shaped polymers: A model for the conformation and its concentration dependence. J. Phys. 1982, 43, 531-538. [CrossRef]

69. Sung, J.H.; Lee, D.C. Molecular shape of poly(2-ethyl-2-oxazoline) chains in THF. Polymer 2001, 42, 5771-5779. [CrossRef]

70. Tsvetkov, V.N.; Lavrenko, P.N.; Bushin, S.V. A hydrodynamic invariant of polymeric molecules. Russ. Chem. Rev. 1982, 51, 975-993. [CrossRef]

71. Tsvetkov, V.N.; Lavrenko, P.N.; Bushin, S.V. Hydrodynamic invariant of polymer-molecules. J. Polym. Sci. Polym. Chem. Ed. 1984, 22, 3447-3486. [CrossRef]

72. Pavlov, G.M.; Korneeva, E.V.; Roy, R.; Michailova, N.A.; Ortega, P.C.; Perez, M.A. Sedimentation, translational diffusion, and viscosity of lactosylated polyamidoamine dendrimers. Progr. Colloid Polym. Sci. 1999, 113, $150-157$.

73. Lin, P.; Clash, C.; Pearce, E.M.; Kwei, T.K.; Aponte, M.A. Solubility and miscibility of poly(ethyl-oxazoline). J. Polym. Sci. Part B Polym. Phys. 1988, 26, 603-619. [CrossRef]

74. Christova, D.; Velichkova, R.; Loos, W.; Goethals, E.J.; Prez, F.D. New thermo-responsive polymer materials based on poly(2-ethyl-2-oxazoline) segments. Polymer 2003, 44, 2255-2261. [CrossRef]

75. Diab, C.; Akiyama, Y.; Kataoka, K.; Winnik, F.M. Microcalorimetric study of the temperature-induced phase separation in aqueous solutions of poly(2-isopropyl-2-oxazolines). Macromolecules 2004, 37, 2556-2562. [CrossRef]

76. Kirile, T.Y.; Tobolina, A.I.; Elkina, A.A.; Kurlykin, M.P.; Tenkovtsev, A.V.; Filippov, A.P. Self-assembly processes in aqueous solutions of eat-sensitive star-shaped poly-2-ethyl-2-oxazoline. Fiber Chem. 2018, 50, $248-251$. [CrossRef]

(C) 2020 by the authors. Licensee MDPI, Basel, Switzerland. This article is an open access article distributed under the terms and conditions of the Creative Commons Attribution (CC BY) license (http://creativecommons.org/licenses/by/4.0/). 